\title{
Factors associated with oral Candida colonization in neonates at intensive care unit
}

\author{
I Putu Wijana, MD; Hendra Santoso, MD; I Made Swastika, MD
}

\begin{abstract}
Background Oral candidiasis still has high prevalence and frequently causes problems in the neonatal period.

Objective To evaluate some factors associated with the occurrence of oral Candida colonization in neonates.

Methods A cross sectional study was performed at the Intensive Care Unit, Neonatology Division, Department of Child Health, Medical School, Udayana University/Sanglah Hospital Denpasar, from November 2002 to April 2003. Eighty neonates were enrolled. Oral mucous swabs were obtained and examined for Candida colonization using potassium hydroxide $(\mathrm{KOH})$. Data were analyzed by prevalence ratio and logistic regression; a $p$ value of $<0.05$ was considered significant.

Results The prevalence of oral Candida colonization was 55\% (44/80). The colonization was significantly associated with age of $>1$ week, male sex, gestational age of $<37$ weeks, Apgar score of $<7$, birth weight of $<1500$ grams, oral mucous $\mathrm{pH}$ of $<7$, systemic antibiotic use, and steroid use by mother. Breastfeeding was a protective factor. Correlation between variables using Spearman test revealed correlation coefficient of $<0.5$. By logistic regression, birth weight of $<1500$ grams $(p=0.04)$ and systemic antibiotic use $(p=0.01)$ were significant associated factors of oral Candida colonization, while breastfeeding was a significant protective factor $(p=0.03)$.

Conclusion Birth weight of $<1500$ grams and systemic antibiotic use were significant associated factors of oral Candida colonization and breastfeeding was a significant protective factor of oral Candida colonization in neonates [Paediatr Indones 2004;44:188-192].
\end{abstract}

Keywords: neonatal, preterm, oral Candida colonization, $\mathrm{KOH}$ examination

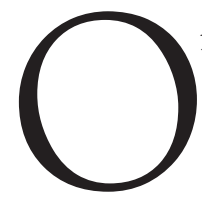
ral candidiasis is a common opportunistic infection of the oral cavity caused by overgrowth of Candida albicans. ${ }^{1-5}$ The risk factors are prematurity, prolonged systemic antibiotic, corticosteroid, or aminophylline treatment, and formula feeding. ${ }^{2,6,7} \mathrm{~A}$ neonate, especially a preterm, has an immature and uninitiated immune response that can lead to enhanced susceptibility to infection of Candida. Neutrophils, macrophages, and lymphocytes have a major role in protecting the host against Candida infection. 2,8-11 Acute pseudomembrane is the most common sign of oral candidiasis. Pseudomembranous candidiasis is characterized by extensive white pseudomembrane consisting of desquamated epithelial cells, fibrin, and fungal hyphae. These white patches occur on the surface of the labial and buccal mucous membrane, tongue, and oropharynx. The patches can usually be scraped off with a swab to expose an underlying erythematous mucosa. ${ }^{2,12-14}$

The incidence of oral candidiasis varies depending on age and certain predisposing factors. Reported peak incidence was around the second week of life. The incidence of oral candidiasis was equal in males and females. Akpan ${ }^{15}$ reported that the incidence of Candida albicans isolated from the oral cavity of neonates was $45 \%$. In the USA, ${ }^{14}$ as many as $37 \%$ of newborns may develop oral candidiasis

From the Departments of Child Health (IPW, HS); Dermato-Venereology (IMS), Medical School, Udayana University, Sanglah Hospital, Denpasar, Indonesia

Reprint requests to: I Putu Wijana, MD, Department of Child Health, Medical School, Udayana University, Sanglah Hospital, Denpasar, Jalan Nias, Denpasar, Indonesia. Tel. 62-361-227911-15 Ext. 128; Fax. $62-$ 361-244038, email: ikaunud@centrin.net.id. 
during the first months of life. Rippon ${ }^{2}$ reported that oral candidiasis in neonates was about 23\%. In Cipto Mangunkusumo Hospital, Jakarta, Aisah ${ }^{16}$ found that $76 \%$ of diaper rash cases in neonates are caused by Candida albicans. The purpose of this study was to evaluate some associated factors of the occurrence of oral Candida colonization in neonates.

\section{Methods}

This was a cross-sectional study, conducted from November 2002 until April 2003. The inclusion criteria were newborns hospitalized in the intensive care unit, Sanglah Hospital whose parents agreed to follow the procedure of this study. Infants with incomplete medical records are excluded.

The sample size was calculated based on an assumption that the incidence rate of oral Candida colonization in neonates was approximately $37 \%$. A minimal sample of 80 was required ( $\mathrm{p}<0.05$, power $80 \%)$.

Subjects were recruited consecutively. Demographic data (birth weight, sex, gestational age, mode of delivery) were retrieved from medical records. Clinical data (clinical manifestation and oral mucous $\mathrm{pH}$ ) were collected through the examination of the patients.

Statistical analysis was done using SPSS 10.0 for Windows computer program. Comparison between the study groups for nominal variables was performed with the chi-square test. Associated factors of oral Candida colonization (age of $>1$ week, gestational age of $<37$ weeks, male sex, Apgar score of $<7$, birth weight of $<1500$ grams, oral mucous $\mathrm{pH}$ of $<7$, systemic antibiotic treatment, steroid use by mother, mode of delivery, and breastfeeding) were evaluated by prevalence ratio (PR) and 95\% confidence interval (95\%CI). Correlation between factors and oral Candida colonization were evaluated with Spearman test. Variables with $\mathrm{p}$ value of $<0.05$ by univariate analysis were calculated into multiple regression analysis. A $p$ value of $<0.05$ was considered significant. ${ }^{17-19}$

\section{Results}

\section{Subjects' characteristics}

During November 2002 to April 2003, 80 infants were enrolled in this study. No infant received steroid or aminophylline treatment. Forty-three of 80 (54\%) were girls and 37 (46\%) were boys. The mean gestational age was 34.5 weeks (SD 2.9) and the mean chronological age was 7.7 days (SD 2.9).

\section{Prevalence ratio}

The total frequency of oral Candida colonization was 44 of 80 subjects $(55 \%)$. Some factors had significant prevalence ratio $(\mathrm{PR}>1)$ and $p$ value of $<0.05$ for oral Candida colonization (Table 1). Factor insignificantly associated with oral candidiasis was mode of delivery, while breastfeeding was proven as a significant protective factor. Systemic antibiotic usage had the highest prevalence ratio $(\mathrm{PR}=2.77)$, followed by age of $>1$ week $(\mathrm{PR}=2.38)$, and oral mucous $\mathrm{pH}(\mathrm{PR}=2.21)$.

Table 1. Prevalence ratio of associated factors of oral CANDIDA COLONIZATION IN NEONATES

\begin{tabular}{|c|c|c|c|c|c|}
\hline Associated factors & $\begin{array}{c}\mathbf{K O H} \\
\text { positive }\end{array}$ & $\begin{array}{c}\text { KOH } \\
\text { negative }\end{array}$ & PR & $95 \% \mathrm{Cl}$ & $\mathbf{p}$ \\
\hline \multicolumn{6}{|l|}{ Age } \\
\hline$\geq 1$ week & 34 & 13 & 2.38 & $1.38 ; 4.12$ & 0.00 \\
\hline$<1$ week & 10 & 23 & & & \\
\hline \multicolumn{6}{|l|}{ Sex } \\
\hline Male & 25 & 12 & 1.52 & $1.02 ; 2.28$ & 0.03 \\
\hline Female & 19 & 24 & & & \\
\hline \multicolumn{6}{|l|}{ Gestational age } \\
\hline$<37$ weeks & 33 & 17 & 1.80 & $1.08 ; 2.95$ & 0.01 \\
\hline$\geq 37$ weeks & 11 & 19 & & & \\
\hline \multicolumn{6}{|l|}{ Apgar score } \\
\hline$<7$ & 31 & 12 & 2.05 & $1.27 ; 3.30$ & 0.001 \\
\hline$\geq 7$ & 13 & 24 & & & \\
\hline \multicolumn{6}{|l|}{ Birth weight } \\
\hline$<1500$ grams & 23 & 9 & 1.64 & $1.11 ; 2.42$ & 0.01 \\
\hline$\geq 1500$ grams & 21 & 27 & & & \\
\hline \multicolumn{6}{|l|}{ Oral mucous $\mathrm{pH}$} \\
\hline$<7$ & 33 & 13 & 2.21 & $1.32 ; 3.72$ & 0.001 \\
\hline$\geq 7$ & 11 & 23 & & & \\
\hline \multicolumn{6}{|l|}{ Systemic antibiotic } \\
\hline Yes & 39 & 20 & 2.77 & $1.26 ; 6.09$ & 0.001 \\
\hline No & 5 & 16 & & & \\
\hline \multicolumn{6}{|l|}{ Steroid use by mother } \\
\hline Yes & 23 & 10 & 1.56 & $1.05 ; 2.30$ & 0.02 \\
\hline No & 21 & 26 & & & \\
\hline \multicolumn{6}{|l|}{ Mode of delivery } \\
\hline Vaginam & 34 & 27 & 1.05 & $0.65 ; 1.71$ & 0.81 \\
\hline Non Vaginam & 10 & 9 & & & \\
\hline \multicolumn{6}{|l|}{ Breastfeeding } \\
\hline Yes & 10 & 25 & 0.37 & $0.21 ; 0.65$ & 0.00 \\
\hline No & 34 & 11 & & & \\
\hline
\end{tabular}

\section{Correlation}

According to Spearman test, there was a weak positive correlation between age of $<1$ week and oral Candida colonization, while breastfeeding had a weak negative 
Paediatrica Indonesiana

Table 2. Correlation matrix between associated factors and oral Candida colonization in neonates

\begin{tabular}{|c|c|c|c|c|c|c|c|c|c|}
\hline & & Age & Sex & BW & GA & AS & pH & $A B$ & SteroidBreastfeeding \\
\hline Candidiasis & $r$ & $\begin{array}{c}0.416 \\
0.00\end{array}$ & 0.234 & $\begin{array}{l}0.277 \\
0.013\end{array}$ & $\begin{array}{c}0.285 \\
0.01\end{array}$ & 0.370 & 0.374 & $\begin{array}{c}0.391 \\
0.00\end{array}$ & -0.469 \\
\hline
\end{tabular}

r. correlation coefficient, $\mathrm{KOH}$ : potassium hidroxyde, BW: birth weight; GA: gestational age; AS: Apgar score.

$A B$ : systemic antibiotic

correlation with oral candidiasis $(\mathrm{r}=-0.469, \mathrm{p}<0.0001)$. The complete values of coefficient correlation and $p$ values can be seen in Table 2 .

\section{Logistic regression analysis}

Table 3 shows that independent variables significantly associated with oral Candida colonization were systemic antibiotic use $(\mathrm{OR}=5.53, \mathrm{p}=0.01)$, birth weight of $<1500$ grams $(\mathrm{OR}=4.85, \mathrm{p}=0.04)$, and breastfeeding $(\mathrm{OR}=0.31, \mathrm{p}=0.03)$. On the other hand, age of $>1$ week, gender, gestational age, Apgar score, oral mucous $\mathrm{pH}$, and steroid use by mother had no significant association with oral Candida colonization.

\section{Discussion}

The prevalence of oral Candida colonization in this study was 55\% (44/80). Similar results were reported by Akpan (40-45\%), ${ }^{15}$ Gupta et al (32\%), ${ }^{20}$ and Mudra (37\%). ${ }^{14}$ We found that the prevalence of oral Candida colonization was significantly higher in neonates with age of $\geq 1$ week compared to that in neonates of $<1$ week $(\mathrm{p}<0.0001, \mathrm{PR}=2.38$, $95 \%$ CI $1.38 ; 4.12$ ). Baley et $a^{21}$ found that $66 \%$ of Candida albicans colonization in VLBW occur in the second week of life, which is similar to that reported by Gupta et al20.
The colonization of oral Candida occurred more frequently in males compared to females $(\mathrm{p}=0.03$, $\mathrm{PR}=1.59,95 \%$ CI 1.02;2.28). Gupta et al20 reported that oral candidiasis is significantly more frequent in males. Colonization of oral candida also occurred more frequently in neonates with gestational age of $<37$ weeks compared to those of $\geq 37$ weeks $(\mathrm{p}=0.01, \mathrm{PR}=1.8$, $95 \%$ CI $1.08 ; 2.99)$. Baley et a ${ }^{22}$ reported that $26 \%$ of Candida colonization occur in preterm neonates, while Kaufman et $a^{23}$ found this proportion to be $50 \%$.

In this study, the colonization of oral Candida more frequently occurred in neonates with asphyxia during delivery compared to those without, with a $\mathrm{p}$ value of $<0.0001$ and $\mathrm{PR}=2.05$ (95\%CI 1.27;3.3). Similar result was also reported by Gupta et al ${ }^{20}$. The colonization of oral Candida in neonates with birth weight of $<1500$ grams was higher compared to that of $\geq 1500$ grams $(\mathrm{p}=0.01, \mathrm{PR}=1.64,95 \% \mathrm{CI}$ $1.11 ; 2.42)$. Baley et $a^{21}$ found that the prevalence of Candida colonization in VLBW neonates was $46 \%$. In this study, the colonization of oral Candida was significantly more frequent in neonates with oral mucous $\mathrm{pH}$ of $<7$ compared to that of $\geq 7$ ( $\mathrm{p}<0.001$, $\mathrm{PR}=2.2195 \%$ CI $1.32 ; 3.72$ ).

The increasing use of antibiotics, particularly the broad-spectrum ones, has resulted in increasing incidence of Candida colonization. In this study, the prevalence of oral Candida colonization was higher in neo-

Table 3. Multivariate logistic Regression analysis

\begin{tabular}{llllll}
\hline Variables & B & SE & p & OR & $\mathbf{9 5 \% C l}$ \\
\hline 1. Age & 0.50 & 0.73 & 0.48 & 1.66 & $0.39 ; 6.97$ \\
2. Sex & 0.52 & 0.68 & 0.44 & 1.69 & $0.44 ; 6.52$ \\
3. Birth weight of $<1500 \mathrm{~g}$ & 1.57 & 0.77 & 0.04 & 4.85 & $1.06 ; 22.06$ \\
4. Gestational age & 0.82 & 0.70 & 0.53 & 1.54 & $0.38 ; 6.15$ \\
5. Apgar score & 0.86 & 0.84 & 0.32 & 2.28 & $0.43 ; 12.05$ \\
6. Oral mucous pH & 0.86 & 0.68 & 0.20 & 2.37 & $0.62 ; 9.10$ \\
7. Systemic antibiotic use & 1.71 & 0.70 & 0.01 & 5.53 & $1.38 ; 22.16$ \\
8. Steroid use by mother & -0.52 & 0.97 & 0.59 & 0.59 & $0.08 ; 4.03$ \\
9. Breastfeeding & -1.40 & 0.65 & 0.03 & 0.31 & $0.69 ; 0.88$ \\
\hline
\end{tabular}

190 - Paediatrica Indonesiana, Vol. 44, No. 9-10 • September - October 2004 
nates with systemic antibiotic use compared to those of without $(\mathrm{p}<0.0001, \mathrm{PR}=2.77,95 \% \mathrm{CI} 1.26 ; 6.09)$. Similar result was reported by Gupta et al. ${ }^{20}$.

The use of corticosteroids, which may change flora as well as function of immune modulators, is also a risk factor for oral candidiasis. ${ }^{6}$ Neonates delivered from mothers using corticosteroids had higher prevalence of oral candidiasis compared to those who were not $(\mathrm{p}=0.02, \mathrm{PR}=1.56,95 \% \mathrm{CI}$ 1.05;2.30). Botas $^{24}$ reported that the administration of intravenous corticosteroid significantly increases the risk of Candida infection in preterm infants. Hope $^{25}$ found that $60 \%$ of immunocompetent infants have signs of oropharyngeal thrush.

Oral colonization of Candida in breastfed neonates was lower compared to that in formula fed neonates $(\mathrm{p}<0.0001, \mathrm{PR}=0.37,95 \%$ CI $0.21 ; 0.65)$. Breastfeeding is a protective factor against oral candidiasis because breast milk contains SIgA, IgM, IgG, lactoferrin, lactoperoxidase, lysozym, macrophages, and neutrophils. ${ }^{2,26}$ Oral colonization of Candida was not significantly different between vaginally and non-vaginally delivered neonates $(p=0.81, P R=1.05,95 \% C I$ $0.65 ; 1.7)$. These results differ from those of Baley ${ }^{21}$ who stated that Candida colonization was significantly more frequent in neonates with vaginal delivery.

By Spearman test, two factors had weak correlations with oral candidiasis i.e., age of $>1$ week and breastfeeding, while other factors did not have significant statistical correlation. By multivariate analysis, three factors had significant association with oral Candida colonization in neonates i.e., birth weight $<1500$ grams $(\mathrm{p}=0.04 ; \mathrm{OR}=4.85 ; 95 \% \mathrm{CI}$ $1.06 ; 6.52)$, systemic antibiotic use $(\mathrm{p}=0.01, \mathrm{OR}$ $=5.53 ; 95 \% \mathrm{CI} 1.38 ; 22.16)$, and breastfeeding $(\mathrm{p}=0.31 ; \mathrm{OR}=0.31 ; 95 \% \mathrm{CI} 0.69 ; 0.88)$.

In conclusion, there are three independent factors associated with oral Candida colonization in neonates i.e., birth weight of $<1500$ grams, systemic antibiotic use, and breastfeeding which is a protective factor.

\section{References}

1. Miller MJ. Fungal infection. In: Klein JO, Remington JS, editors. Infectious diseases of the fetus \& newborn infant. $4^{\text {th }}$ ed. Philadelphia: Saunders; 1995. p.703-43.
2. Rippon JW. Medical mycology. $2^{\text {nd }}$ ed. Philadelphia: Saunders; 1982. p. 484-501.

3. Lay KM, Russel C. Candida species and yeasts in mouths of infants from a special care unit of a maternity hospital. Arch Dis Child 1987;52:794-6.

4. Melnick JL. Medical mycology. In: Jawetz E, editor. Review of medical microbiology. $15^{\text {th }}$ ed. California: Lange Medical Publication; 1982. p. 297-9.

5. Hughes PA, Martha L, Harry H. Neonatal candidiasis. In: Bodey GP, editor. Pathogenesis, diagnosis, and treatment.

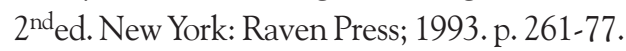

6. Shahe V,Smith CB. Pathogenesis, host resistance, and predisposing factors. In: Bodey GP, editor. Pathogenesis, diagnosis, and treatment. $2^{\text {nd }}$ ed. New York: Raven Press; 1993. p. 59-75.

7. Wade JC. Epidemiology of Candida infection. In: Bodey GP, editor. Pathogenesis, diagnosis, and treatment. $2^{\text {nd }}$ ed. New York: Raven Press; 1993. p. 85-107.

8. Suharno S, Tantien, Evita, Kusmarinah. Mekanisme pertahanan pejamu pada infeksi Kandida. MDVI 2000;27:187-93.

9. Kirkpatrick $\mathrm{CH}$. Immune responses to fungi. In: Rich $\mathrm{R}$, Thomas AF, editors. Clinical immunology principle and practice. Philadelphia: Mosby; 1999. p. 571-7.

10. Roitt I, Brostoff J, Male D. Immunology. $5^{\text {th }} \mathrm{ed}$. Philadelphia: Mosby; 1998. p. 43-54.

11. Thrush or Candidiasis. Available from: URL: http:// www.child.org/dental/thrush.asp.html

12. Neonatal candidiasis. Availabe from: URL: http:// www.doctorfungus.org/fungi_action/ human/candida/ neonatal. htm.

13. Koch H, Graber MA. Pediatrics: neonatal infections. Available from: URL: http://www.vh.org/pediatric/provider/pediatrics/familypracticehanbook/neonatalinfections.html.

14. Mudra K. Oral thrush. Available from: URL: http:// www.emedicine.com/ped/topic25.html.

15. Akpan A, Morgan R. Oral candidiasis. Postgrad Med J 2002;78:455-9.

16. Aisah SB. Lestari TS. Pengobatan kombinasi mikonazol nitrat $0,25 \%$ dan seng oksida $15 \%$ pada penderita dermatitis popok. Presented at PIT IDAI; 2001 June 25; Palembang, Indonesia.

17. Ghazali MV, Sastromiharjo, Soejarwo R. Studi cross sectional. In: Sastroasmoro S, Ismael S, editors. Dasar-dasar metodologi penelitian klinis. $1^{\text {st }}$ ed. Jakarta: Binarupa Aksara; 1995. p. 66-77.

18. Madiyono B, Moeslichan MZ, Perkiraan besar sampel. In: SastroasmoroS, IsmaelS, editors. Dasar-dasarmetodologipenelitian

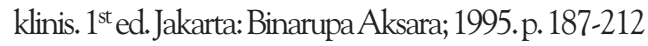




\section{Paediatrica Indonesiana}

19. Sastroasmoro S. Memahami nilaip dan interval kepercayaan dalam studi analitik. Sari Pediatri 1994;1:169-78.

20. Gupta P. Clinical profile and risk factors for oral candidiasis in sick newborns. Indian Pediatr 1996;33:299-303.

21. Baley JE, Kliegman RM, Fanaroff AA. Disseminated fungal infections in very low-birth-weight infant: therapeutic toxicity. Pediatrics 1984;73:153-7.

22. Baley J, Kliegman RM, Boxerbauem, Fanaroff. Fungal colonization in the verylow birth weightinfant. Pediatrics 1986;78:225-32.

23. Kaufman D, Boyle R, Hazen K, Robinson M. Fluconazole prophylaxis against fungal colonization and infection in preterm infants. N Engl J Med 2001;345:1660-6.
24. Botas CM, Kurlat L, Young S. Disseminated Candida infection and intravenous hydrocortisone in preterm infants. Pediatrics 1995;95:883-7.

25. Hoppe JE. Treatment of oropharyngeal candidiasis in immunocompetent infants: a randomized multicenter study of miconazole gel vs nystatin suspension. The anti fungals study group. Pediatr Infect Dis J 1997;16:288-93.

26. Suradi R. Spesifisitas air susu ibu. Presented at The National Scientific Meeting of The Indonesian Society of Pediatricians; 2001 June 25; Palembang, Indonesia. 